\section{Association between Genetic Polymorphisms in RANK, RANKL and OPG and Peri-Implant Diseases in Patients from the Amazon Region}

\author{
Raphael Carvalho e Silva ${ }^{10}$, Marilia Bianchini Lemos Reis ${ }^{2}{ }^{(0)}$ Juliana Arid $^{3}$ \\ (i) Elvira Katherine Barriga Flores ${ }^{4}$, Giuseppe Valduga Cruz ${ }^{4}$, Guido A. \\ Marañón-Vásquez ${ }^{3}{ }^{\mathbb{D}}$, Lizete Karla Filgueiras de Souza ${ }^{1}$, Arthur Belém \\ Novaes Jr. ${ }^{2}{ }^{\circledR}$, Alexandra Mussolino de Queiroz ${ }^{3}{ }^{(0}$, Erika Calvano Küchler ${ }^{3}$ (1)
}

\begin{abstract}
The present study evaluated polymorphisms in RANK, RANKL and OPG-encoding genes to assess whether they are associated with mucositis and peri-implantitis in a population from the Brazilian Amazon region. One hundred and fourteen patients with dental implants were included in the study. After clinical and radiographic examination, the sample was categorized into 4 groups, according to the peri-implant status: Healthy $(n=71)$, Mucositis ( $n=30)$, Peri-implantitis $(n=13)$ and Diseased (Mucositis + Peri-implantitis, $n=43$ ). Genomic DNA was extracted from buccal cells from saliva, and the genetic polymorphism in osteoprotegerin (OPG), Kappa nuclear factor activator receptor (RANKL) and nuclear kappa factor activator receptor (RANK) were genotyped by the real time PCR. Univariate and multivariate statistical analyses were performed to compare clinical variables among groups and to evaluate genotypes and alleles distributions and the established alpha was 5\%. Age, peri-implant biotype, diabetes and presence of peri-implant biofilm were associated with mucositis $(p<0.05)$ and peri-implantitis $(p<0.05)$. Smoking, alcoholism, and periodontal biofilms were also associated with the presence of peri-implantitis $(p<0.05)$. Univariate and multivariate analysis did not demonstrate an association of peri-implantitis or mucositis with any genetic polymorphism in RANK (rs3826620), RANKL (rs9594738) and OPG (rs2073618) ( $p>0.05)$. The studied genetic polymorphism in RANK, RANKL and OPG were not associated with mucositis and peri-implantitis in a Brazilian population from the Amazon region.
\end{abstract}

'Department of Oral and Maxillofacial Surgery and Dental Implants, IAES - Faculdade do Amazonas, Manaus, AM, Brazil ${ }^{2}$ Department of Oral and Maxillofacial Surgery and Periodontology, School of Dentistry of Ribeirão Preto, USP - Universidade de São Paulo, Ribeirão Preto, SP, Brazil ${ }^{3}$ Department of Pediatric Dentistry, School of Dentistry of Ribeirão Preto, USP - Universidade de São Paulo, Ribeirão Preto, SP, Brazil ${ }^{4}$ School of Health Science, UP - Universidade Positivo, Curitiba, PR, Brazil

Correspondence: Erika Calvano Küchler, Avenida do Café S/N, 14040-904 Ribeirão Preto, SP, Brasil. Tel: +55-16-3315-3995. e-mail: erikacalvano@gmail.com

Key Words: dental implants, peri-implantitis, genes, genetic polymorphism, genetics, mucositis.

\section{Introduction}

The peri-implant diseases are known as Mucositis, which is a reversible inflammation of peri-implant tissues, and Periimplantitis, which is an irreversible inflammation that leads to bone loss. They could be identified by redness, soft tissue swelling and bleeding on probing and differed by bone loss to the radiographic exams $(1,2)$. Despite divergences in the definition of peri-implantitis and the differential diagnosis of peri-implant diseases, the studies have estimated that peri-implantitis affects approximately $9 \%$ of implants and $18 \%$ of patients $(3,4)$.

Several factors play a role in the complex etiology of peri-implant diseases, such as history of periodontal disease, poor oral hygiene, oral biofilm composition, tobacco and alcohol consumption, systemic conditions and factors related to the implant, such as surgical technique, implant type, prosthesis design, occlusal loading and genetic factors (5-13).

RANK and RANK-L plays a critical role in the production, differentiation and activation of osteoclasts, leading to bone resorption (14). On the other hand, OPG is a soluble protein whose structure is similar to RANK, which allows it to bind to RANKL, thus blocking the inducing effect of osteoclastogenesis (15). A recent systematic review (16) in different populations demonstrated that genetic polymorphisms in genes from the tumor necrosis factor superfamily, including: RANK (kappa $\beta$ Nuclear Factor Receptor Activator), RANKL (kappa $\beta$ Nuclear Factor Receptor Binding) and OPG (osteprogesterin), are candidate genes for peri-implant disease (14). Nevertheless, the authors pointed out that the results may vary according to the ethnic origin of the population studied $(14,17,18)$, reinforcing the necessity of more studies evaluating genetic polymorphisms involved in peri-implant diseases in different populations. Therefore, the present study evaluated polymorphisms in RANK, RANKL and OPGencoding genes to assess whether they are associated with mucositis and peri-implantitis in a population from the Brazilian Amazon region.

\section{Material and Methods \\ Studied Population}

This study was approved by the Research Ethics Committee from Federal Fluminense University (0061.0.258.000-07) and the patients signed a free and 
informed consent form to participate. The subjects of the present study were patients from the Osseointegrated dental implants Specialization Clinic from Manaus. Manaus is the capital of the state of Amazonas, which is located in the Amazon Brazilian forest.

Sample collection was carried out from 2016 to 2018 and biological unrelated patients with at least one installed dental implant were included in the study. Patients with systemic disease, smokers, e alcoholism and poor oral hygiene were included in the study as a way to evaluate the effect of these environmental factors in the outcome as well as the gene-environmental interaction. Patients who had peri-implant disease or early implant loss both before the osseointegration period were excluded. All the individuals that fulfilled the inclusion criteria were invited to participate and answered a structure questionnaire.

\section{Clinical Assessments}

All clinical and radiographic data were collected by one experienced examiner (R.C.S). Patient's general health, use of medications, habits, history of previous periodontal disease and peri-implant tissue conditions through clinical examination were recorded. According to the characteristics

+ Peri-implantitis). The patient who presented more than one implant was included in the group according to the highest level of disease.

The peri-implant tissue was clinically evaluated for gingival staining, bleeding on probing, spontaneous bleeding, peri-implant phenotype ( $0=$ thin, $1=$ thick $)$, suppuration and bacterial biofilm $(0=$ absence of biofilm, $1=$ presence). The clinical probing depth was measured in the buccal, lingual / palatal, mesial and distal aspects, using a periodontal probe CT-15.

\section{Genotyping Analysis of RANK, RANKL and OPG}

Saliva samples were collected as a source of genomic DNA based on a previously published protocol (19).

Two intronic genetic polymorphism in RANK (rs3826620, $\mathrm{G}>\mathrm{T}$ ), RANKL (rs9594738, C>T) and one missense variant located in exon I of the OPG gene leading to amino acid exchanges Leucine to Asparagine (rs2073618, C>G) were blinded genotyped by real time polymerase chain reactions (Real Time PCR) on StepOnePlus ${ }^{\mathrm{TM}}$ sequence detection system (Applied Biosystems ${ }^{\mathrm{TM}}$, Foster City, USA) using TaqMan assay.

\section{Statistical Analysis}

Descriptive statistics was used to present the characteristics of the sample. Mann-Whitney test or Fisher's exact test were applied to assess the influence of these characteristics over the peri-implant condition. Chi-square or Fisher's exact tests were used to determine the association between genotype and allele frequencies for each polymorphism and the peri-implant phenotype. Univariate and multivariate logistic regression models were applied to assess all variables influencing the peri-implant condition. Chi-square test was also used to evaluate the Hardy-Weinberg equilibrium. All analyses were performed using two-tailed tests $(\alpha=0.05)$ on Epi Info 3.5.2. (www. cdc.gov/epiinfo). The graphical presentation was performed using Prism GraphPad 8.

\section{Results}

A total of 114 patients (age: 19-82; 46 males and 68 females) were included in the study, of which 71 had healthy peri-implant tissues and 43 presented diseased peri-implant tissues (30 were diagnosed with mucositis and 13 with peri-implantitis). Figure 1 presents the gender distribution according to the phenotype (healthy, mucositis and periimplantitis), gender distribution was not statistically different among the groups ( $p>0.05$ ).

Regarding the age, the healthy group was younger than the Mucositis, Peri-implantitis and Diseased groups $(p<0.001$ for all comparisons). Smoke increased the risk of peri-implantitis $(\mathrm{p}=0.004, \mathrm{OR}=7.11,95 \% \mathrm{Cl}=1.93-22.31)$. Thick peri-implant phenotype was more common in healthy group than in Mucositis, Peri-implantitis and Diseased groups ( $p<0.05$ for all comparisons). Periodontal disease was also associated with Peri-implantitis and Diseased groups ( $p=0.003$ and 0.008 , respectively). Pre-implantis biofilm was associated Mucositis, Peri-implantitis and Diseased groups ( $p<0.05$ for all comparisons) Diabetes and alcohol drink habits were also statistically different among the groups $(p<0.05)$. Table 1 demonstrated the associated factors among the groups.

Genotype distributions were within Hardy-Weinberg

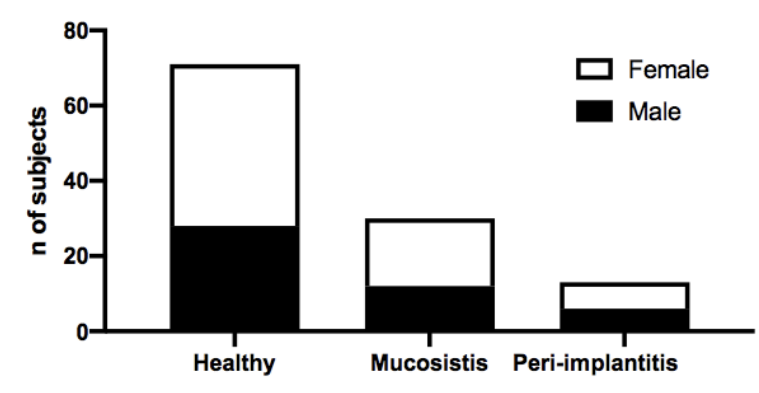

Figure 1. Gender distribution according to the groups: healthy, mucositis and peri-implantitis. 
equilibrium, as follow: (chi-squareH-W was 2.85 for RANK, 0.23 for RANKL, and 0.39 for $\mathrm{OPG}$ ). There were no associations between the peri-implant condition and the genotype or allele frequencies for any polymorphism evaluated in the RANK, RANKL and OPG ( $p>0.05$ ) (Table 2). The multivariate analysis showed that the age $(\mathrm{OR}=6.14$, 95\% $\mathrm{Cl}=1.95-19.38, \mathrm{P}=0.002)$ and a thin peri-implant phenotype (OR=3.41, 95\% $\mathrm{Cl}=1.03-11.24, \mathrm{P}=0.044)$ increased the risk of presenting peri-implant alterations, whereas the absence of peri-implant biofilm decreased its risk (OR=0.06, 95\% $\mathrm{Cl}=0.01-0.58, \mathrm{P}=0.015)$ (Table 3).

\section{Discussion}

Different from mucositis, peri-implantitis is an irreversible inflammatory process that affects not only soft tissues but also surrounding supporting bone of implants

Table 1. Characteristics of the groups

\begin{tabular}{|c|c|c|c|c|c|c|c|}
\hline \multirow{2}{*}{ Characteristics } & \multirow{2}{*}{$\begin{array}{l}\text { Healthy } \\
(\mathrm{n}=71)\end{array}$} & \multirow{2}{*}{$\begin{array}{l}\text { Mucositis } \\
(\mathrm{n}=30)\end{array}$} & \multirow{2}{*}{$\begin{array}{l}\text { Peri-implantitis } \\
\quad(\mathrm{n}=13)\end{array}$} & \multirow{2}{*}{$\begin{array}{l}\text { Diseased } t \\
(\mathrm{n}=43)\end{array}$} & \multicolumn{3}{|c|}{$\mathrm{p}$ values } \\
\hline & & & & & $\begin{array}{l}\text { Healthy vs. } \\
\text { Mucositis }\end{array}$ & $\begin{array}{c}\text { Healthy vs. } \\
\text { Peri-implantitis }\end{array}$ & $\begin{array}{c}\text { Healthy vs. } \\
\text { Diseasedt }\end{array}$ \\
\hline \multicolumn{8}{|l|}{ Age (years) } \\
\hline Min & 19 & 32 & 27 & 27 & & & \\
\hline $\operatorname{Max}$ & 82 & 75 & 77 & 77 & & & \\
\hline Median & 33 & 50 & 52 & 51 & & & \\
\hline Mean (SD) & $35.7(13.0)$ & $51(12.5)$ & $50(14.1)$ & $50.7(12.9)$ & $<0.001^{*}$ & $<0.001^{*}$ & $<0.001^{*}$ \\
\hline \multicolumn{8}{|l|}{ Gender n (\%) } \\
\hline Male & $28(39.4)$ & $12(40.0)$ & $6(46.2)$ & $18(41.9)$ & & & \\
\hline Female & $43(60.6)$ & $18(60.0)$ & $7(53.8)$ & $25(58.1)$ & $>0.999$ & 0.761 & 0.845 \\
\hline \multicolumn{8}{|c|}{ Peri-implant phenotype n (\%) } \\
\hline Thick & 56 (78.9) & $14(46.7)$ & $5(38.5)$ & $19(44.2)$ & & & \\
\hline Thin & $15(21.1)$ & $16(53.3)$ & $8(61.5)$ & $24(55.8)$ & $0.002^{*}$ & $0.005^{*}$ & $<0.001^{*}$ \\
\hline \multicolumn{8}{|c|}{ Smoking habit n (\%) } \\
\hline Smoker & $10(14.1)$ & $2(6.7)$ & $7(53.8)$ & $9(20.9)$ & & & \\
\hline Non-smoker & 61 (85.9) & $28(93.3)$ & $6(46.2)$ & $34(79.1)$ & 0.502 & $0.004^{*}$ & 0.438 \\
\hline \multicolumn{8}{|l|}{ Diabetes n (\%) } \\
\hline Yes & $1(1.4)$ & $5(16.7)$ & $2(15.4)$ & $7(16.3)$ & & & \\
\hline No & 70 (98.6) & 25 (83.3) & $11(84.6)$ & $36(83.7)$ & $0.009^{*}$ & 0.061 & $0.004^{*}$ \\
\hline \multicolumn{8}{|c|}{ Periodontal disease n (\%) } \\
\hline Yes & $18(25.4)$ & $13(43.3)$ & $9(69.2)$ & $22(51.2)$ & & & \\
\hline No & 53 (74.6) & 17 (56.7) & $4(30.8)$ & $21(48.8)$ & 0.099 & $0.003^{*}$ & $0.008^{*}$ \\
\hline \multicolumn{8}{|c|}{ Peri-implant biofilm n (\%) } \\
\hline Presence & $47(66.2)$ & 29 (96.7) & $13(100.0)$ & $42(97.7)$ & & & \\
\hline Absence & $24(33.8)$ & $1(3.3)$ & $0(0.0)$ & $1(2.3)$ & $<0.001^{*}$ & $0.016^{*}$ & $<0.001^{*}$ \\
\hline \multicolumn{8}{|c|}{ Alcohol drinking habit n (\%) } \\
\hline Alcoholic & $15(21.1)$ & $5(16.7)$ & $7(53.8)$ & $12(27.9)$ & & & \\
\hline Non-alcoholic & $56(78.9)$ & $25(83.3)$ & $6(46.2)$ & $31(72.1)$ & 0.786 & $0.034^{*}$ & 0.497 \\
\hline \multicolumn{8}{|c|}{ Use of medication $\mathrm{n}(\%)$} \\
\hline Yes & 27 (38.0) & $13(43.3)$ & $9(69.2)$ & $22(51.2)$ & & & \\
\hline No & $44(62.0)$ & $17(56.7)$ & $4(30.8)$ & $21(48.8)$ & 0.660 & 0.065 & 0.179 \\
\hline
\end{tabular}

${ }^{*} \mathrm{p} \leq 0.05$ indicates statistically significant difference/association. + Mucositis + Peri-implantitis 
in occlusal function $(7,10,16,17)$. In fact, dental implant failure is a multifactorial condition, in which genetic polymorphisms can affect levels of gene expression and production or protein functions; as a consequence, they may influence the secretion of inflammatory cytokines and regulate the inflammatory responses and the susceptibility to the disease. The RANK/RANKL/OPG system has a significant role in the production and activation of osteoclasts, and therefore in the regulation of bone resorption, possibly affecting the progression of periimplantitis $(17,18)$.

Previous studies evaluated the association between genetic polymorphisms with peri-implantitis in different populations (20-25). However, this is the first study to evaluate patients from the Amazon area. It is important to emphasize that this population has a different genetic background than other areas of Brazil, and they present a higher mixture with native indigenous populations.

In the present study, the association between the genetic polymorphisms rs3826620 in RANK, rs9594738 in RANKL and rs2073618 in OPG and peri-implant diseases was evaluated. As indicated in the results, there were no significant association found between the genetic $\vec{s}$ polymorphisms and peri-implant diseases.

Although just few studies evaluated the association between the genetic polymorphisms in RANK/RANKL/
OPG system with peri-implant diseases, the differences in the results of these studies may demonstrate the ethnic diversity of populations. In 2012, Kadkhodazadeh et al. (20) described that OPG (G1181C) was associated with periimplantitis. In 2013 (21), it was also found an association between the rs9533156 in RANKL with peri-implantitis, and both studies were conducted in Iranian populations. In Belgrade, Rakic et al. (22) observed an association of increased RANK concentration in samples of peri-implant/ gingival crevicular fluid with peri-implant, and in 2014 (23), suggested that concentrations of RANK, RANKL, OPG were different in patients with peri-implantitis compared with patients with healthy peri-implant tissues In a Chinese population, Zhou et al. (24) investigated the OPG rs2073618 and rs2073617 polymorphisms in peri-implantitis and concluded that only the rs2073618 may be associated to the risk of peri-implantitis, but not rs2073617. Ribeiro et al. (25) has not found an association of RANKL (-438) with implant failure in a Brazilian population.

Regarding the risk factors, there is substantial evidence in the literature that poor oral hygiene, history of periodontitis, and smoking are associated with peri-implant diseases $(7,10,11)$.

Although dental implant treatment is highly successful, as reported in the scientific literature, clinicians should expect complications within their daily practice. In this

Table 2. Genotype and allele frequencies according to the peri-implant status

\begin{tabular}{|c|c|c|c|c|c|c|c|c|}
\hline & \multirow{2}{*}{$\begin{array}{l}\text { Healthy } \\
\quad=71) \\
n(\%)\end{array}$} & \multirow[t]{2}{*}{ (n } & \multirow{2}{*}{$\begin{array}{l}\text { Mucositis } \\
(\mathrm{n}=30) \\
\mathrm{n}(\%)\end{array}$} & \multirow{2}{*}{$\begin{array}{l}\text { Periimplantitis } \\
\qquad \begin{array}{c}(\mathrm{n}=13) \\
\mathrm{n}(\%)\end{array}\end{array}$} & \multirow{2}{*}{$\begin{array}{l}\text { Diseased } t \\
(\mathrm{n}=43) \\
\mathrm{n}(\%)\end{array}$} & \multicolumn{3}{|c|}{$\mathrm{p}$ values } \\
\hline & & & & & & $\begin{array}{l}\text { Healthy vs. } \\
\text { Mucositis }\end{array}$ & $\begin{array}{l}\text { Healthy vs. } \\
\text { Peri-implantitis }\end{array}$ & $\begin{array}{l}\text { Healthy vs. } \\
\text { Diseasedt }\end{array}$ \\
\hline \multicolumn{9}{|c|}{ RANK rs3826620 } \\
\hline GG & $33(46.5)$ & & $14(46.7)$ & $9(69.2)$ & $23(53.5)$ & \multirow{3}{*}{0.978} & \multirow{3}{*}{0.214} & \multirow{3}{*}{0.742} \\
\hline GT & $35(49.3)$ & & $15(50.0)$ & $3(23.1)$ & $18(41.9)$ & & & \\
\hline TT & $3(4.2)$ & & $1(3.3)$ & $1(7.7)$ & $2(4.7)$ & & & \\
\hline G & $101(71.1)$ & & 43 (71.7) & $21(80.8)$ & $64(74.4)$ & \multirow{2}{*}{$>0.999$} & \multirow{2}{*}{0.351} & \multirow{2}{*}{0.648} \\
\hline $\mathrm{T}$ & $41(28.9)$ & & $17(28.3)$ & $5(19.2)$ & $22(25.6)$ & & & \\
\hline \multicolumn{9}{|c|}{ RANKL rs9594738 } \\
\hline $\mathrm{CC}$ & 34 (47.9) & & $12(40.0)$ & $4(30.8)$ & $16(37.2)$ & \multirow{3}{*}{0.478} & \multirow{3}{*}{0.522} & \multirow{3}{*}{0.420} \\
\hline $\mathrm{CT}$ & $29(40.8)$ & & $16(53.3)$ & $7(53.8)$ & $23(53.5)$ & & & \\
\hline $\mathrm{TT}$ & $8(11.3)$ & & $2(6.7)$ & $2(15.4)$ & $4(9.3)$ & & & \\
\hline $\mathrm{C}$ & $97(68.3)$ & & $40(66.7)$ & $15(57.7)$ & $55(64.0)$ & \multirow{2}{*}{0.870} & \multirow{2}{*}{0.366} & \multirow{2}{*}{0.563} \\
\hline $\mathrm{T}$ & $45(31.7)$ & & $20(33.3)$ & $11(42.3)$ & $31(36.0)$ & & & \\
\hline \multicolumn{9}{|c|}{ OPG rs2073618 } \\
\hline $\mathrm{CC}$ & $22(33.3)$ & & $11(40.7)$ & $6(60.0)$ & $17(45.9)$ & \multirow{3}{*}{0.703} & \multirow{3}{*}{0.221} & \multirow{3}{*}{0.444} \\
\hline CG & $30(45.5)$ & & $12(44.4)$ & $2(20.0)$ & $14(37.8)$ & & & \\
\hline GG & $14(21.2)$ & & $4(14.8)$ & $2(20.0)$ & $6(16.2)$ & & & \\
\hline C & $74(56.1)$ & & $34(63.0)$ & $14(70.0)$ & $48(64.9)$ & \multirow{2}{*}{0.417} & \multirow{2}{*}{0.332} & \multirow{2}{*}{0.239} \\
\hline G & $58(43.9)$ & & $20(37.0)$ & $6(30.0)$ & $26(35.1)$ & & & \\
\hline
\end{tabular}

+ Mucositis + Peri-implantitis. 
context, the etiology of peri-implantitis has yet to be fully understood and the lack of knowledge about methods for early detection and diagnosis of this complication remains an issue. Based on currently available evidences, no definitive genetic marker can be associated with periimplantitis diseases. Although this study presented a small sample size and only three specific polymorphisms were analyzed, the differences among different geographic populations may impact more in the results. Because of the limited number of studies in the Brazilian population and small study samples, further investigations seem crucial to enlighten this issue. Additional studies are necessary to evaluate other polymorphisms in RANK, RANKL and OPG that may have an influence on peri-implantitis pathologies. In a near future, genetic studies in different populations would contribute to the development of early diagnosis of peri-implantitis. Not only to measure intensity and to estimate progression, but also for the monitoring of both healthy and treated patients (18).

There was no association between peri-implant diseases and the genetic polymorphisms evaluated in the RANK, RANKL and OPG. Age, peri-implant phenotype, diabetes,

Table 3. Regression analysis for the outcome variable "peri-implant condition diseased" (Mucositis + Peri-implantitis)

\begin{tabular}{|c|c|c|c|c|}
\hline \multirow{2}{*}{ Variables } & \multicolumn{2}{|c|}{ Univariate analysis } & \multicolumn{2}{|c|}{ Multivariate analysis } \\
\hline & $p$ value & OR $(95 \% \mathrm{Cl})$ & $P$ value & OR $(95 \% \mathrm{Cl})$ \\
\hline \multicolumn{5}{|l|}{ RANK rs3826620 } \\
\hline GG & Reference & & Reference & \\
\hline GT & 0.444 & $0.74(0.34-1.61)$ & 0.257 & $0.51(0.16-1.63)$ \\
\hline$\pi$ & 0.963 & $0.96(0.15-6.19)$ & 0.414 & $0.33(0.02-4.71)$ \\
\hline \multicolumn{5}{|l|}{ RANKL rs9594738 } \\
\hline $\mathrm{CC}$ & Reference & & Reference & \\
\hline СT & 0.205 & $1.69(0.75-3.78)$ & 0.744 & $1.22(0.38-3.91)$ \\
\hline$\pi$ & 0.929 & $1.06(0.28-4.06)$ & 0.977 & $1.03(0.16-6.52)$ \\
\hline \multicolumn{5}{|l|}{ OPG rs2073618 } \\
\hline CC & Reference & & Reference & \\
\hline CG & 0.270 & $0.69(0.25-1.48)$ & 0.178 & $0.43(0.12-1.47)$ \\
\hline GG & 0.314 & $0.56(0.18-1.75)$ & 0.146 & $0.29(0.05-1.54)$ \\
\hline \multicolumn{5}{|l|}{ Age } \\
\hline$\leq 38$ years & Reference & & Reference & \\
\hline$>38$ years & $<0.001^{*}$ & $7.35(3.09-17.51)$ & $0.002^{*}$ & $6.14(1.95-19.38)$ \\
\hline \multicolumn{5}{|c|}{ Peri-implant phenotype } \\
\hline Thick & Reference & & Reference & \\
\hline Thin & $<0.001^{*}$ & $4.72(2.06-10.80)$ & $0.044^{*}$ & $3.41(1.03-11.24)$ \\
\hline \multicolumn{5}{|l|}{ Smoking habit } \\
\hline Smoker & Reference & & Reference & \\
\hline Non-smoker & 0.345 & $0.62(0.23-1.67)$ & 0.303 & $0.39(0.07-2.33)$ \\
\hline \multicolumn{5}{|l|}{ Diabetes } \\
\hline Yes & Reference & & Reference & \\
\hline No & $0.016^{*}$ & $0.07(0.01-0.62)$ & 0.186 & $0.05(0.00-4.06)$ \\
\hline \multicolumn{5}{|c|}{ Periodontal disease } \\
\hline Yes & Reference & & Reference & \\
\hline No & $0.006^{*}$ & $0.32(0.15-0.72)$ & 0.361 & $0.56(0.16-1.96)$ \\
\hline \multicolumn{5}{|c|}{ Peri-implant plaque } \\
\hline Presence & Reference & & Reference & \\
\hline Absence & $0.003^{*}$ & $0.05(0.01-0.36)$ & $0.015^{*}$ & $0.06(0.01-0.58)$ \\
\hline \multicolumn{5}{|c|}{ Alcohol drinking habit } \\
\hline Alcoholic & Reference & & Reference & \\
\hline Non-alcoholic & 0.410 & $0.69(0.29-1.66)$ & 0.783 & $0.82(0.20-3.43)$ \\
\hline
\end{tabular}

* $\mathrm{p} \leq 0.05$ indicates statistically significant association. 
presence of peri-implant biofilm, smoking, alcoholism and periodontal disease were associated with peri-implant status.

\section{Resumo}

0 presente estudo avaliou a associação da predisposição clínica e dos fatores genéticos com a presença de doenças peri-implantares. Cento e quatorze pacientes com implantes dentais instalados na Clínica de Especialização do Amazonas, Brazil, foram incluidos no estudo. Após exame clínico e radiográfico, a amostra foi categorizada em 4 grupos, de acordo com o Status peri-implantar: saúde $(n=71)$, mucosite $(n=30)$, peri-implantite $(n=13)$ e doentes (mucosite + peri-implantite). DNA genômico foi extraido de células orais da saliva, e o polimorfismo genético em osteoprotegerina (OPG), ligante do receptor ativador do fator Kappa nuclear (RANKL) e receptor ativador do fator Kappa nuclear (RANK) foram genotipados por PCR em tempo real. 0 estudo se propôs a avaliar se os polimorfismos em RANK, RANKL e OPG estão envolvidos na patogênese da mucosite e da peri-implantite, e avaliar também a presença de fatores de risco moduladores da resposta em uma população brasileira. Idade, biotipo peri-implantar, diabetes e presença de biofilme peri-implantar foram associados a mucosite $(p<0.05)$ e peri-implantite $(p<0.05)$. Tabagismo, alcoolismo e biofilme periodontal também foram associados com a presença de peri-implantite $(p<0.05)$. Análise univariada e multivariada não demonstraram associação de peri-implantite ou mucosite com os polimorfismos genéticos em RANK (rs3826620), RANKL (rs9594738) e OPG (rs2073618) ( $p>0.05)$. Os polimorfismos genéticos estudados não foram associados com mucosite e peri-implantite em uma população brasileira da região Amazônica.

\section{Acknowledgements}

This work was supported by the São Paulo Research Foundation (FAPESP) (ECK funding number: 2015/06866-5), individual scholarships (FAPESP and CAPES)

\section{References}

1. Lindhe J and Meyle J. Peri-implant diseases: Consensus Report of the Sixth European Workshop on Periodontology. Journal of Clinical Periodontology, 2008;35:282-285.

2. Atieh MA, Alsabeeha NH, Faggion CM Jr, Duncan WJ. The frequency of periimplant diseases: a systematic review and meta-analysis. J Periodontol 2013;84:1586-1598.

3. Albrektsson T, Buser D, Sennerby L. Crestal bone loss and oral implants. Clin Implant Dent Relat Res 2012;14:783-791.

4. Mombelli A, M€uller N, Cionca N. The epidemiology of peri-implantitis. Clin Oral Implants Res 2012;23:67-76.

5. Chrcanovic BR, Kisch J, Albrektsson T, Wennerberg A. Factors Influencing Early Dental Implant Failures. J Dent Res 2016;95:995-1002

6. Chrcanovic BR, Albrektsson T, Wennerberg A. Reasons for failures of oral implants. J Oral Rehabil 2014;41:443-476

7. Qian J, Wennerberg A, Albrektsson T. Reasons for marginal bone loss around oral implants. Clin Implant Dent Relat Res 2012;14:792-807.

8. Albrektsson T, Buser D, Sennerby L On crestal/marginal bone loss around dental implants. Int J Oral Maxillofac Implants 2012;27:736-738.

9. Albrektsson T, Dahlin C, Jemt T, Sennerby L, Turri A, Wennerberg A.
Is marginal bone loss around oral implants the result of a provoked foreign body reaction? Clin Implant Dent Relat Res 2014;16:155-165.

10. Heitz-Mayfield $\sqcup$. Peri-implant diseases: diagnosis and risk indicators. J Clin Periodontol 2008;35:292-304.

11. Chrcanovic BR, AlbrektssonT, Wennerberg A. Diabetes and Oral Implant Failure: A Systematic Review. J Dent Res 2014;93:859-867.

12. Montes $C C$, Alvim-Pereira $F$, de Castilhos BB, Sakurai ML, Olandoski M, Trevilatto PC. Analysis of the association of IL1B (C+3954T) and IL1RN (intron 2) polymorphisms with dental implant loss in a Brazilian population. Clin Oral Implants Res 2009;20:208-217.

13. Jepsen S, Berglundh T, Genco R, Aass AM, Demirel K, Derks J, Figuero E, et al. Primary prevention of peri-implantitis: managing peri-implant mucositis. J Clin Periodontol 2015;42:152-157.

14. González-Galván MDC, Mosqueda-Taylor A, Bologna-Molina R, SetienOlarra A, Marichalar-Mendia X, Aguirre-Urizar JM. Evaluation of the osteoclastogenic process associated with RANK / RANK-L / OPG in odontogenic myxomas. Med Oral Patol Oral Cir Bucal 2018;23:e315

15. Oliveira MC, Arntz OJ, Blaney Davidson EN, van Lent PL, Koenders MI, van der Kraan PM, et al. Milk extracellular vesicles accelerate osteoblastogenesis but impair bone matrix formation. J NutrBiochem 2016;30:74-84.

16. Dereka X, Mardas N, Chin S, Petrie A, Donos N. A systematic review on the association between genetic predisposition and dental implant biological complications. Clin Oral Implants Res 2012;23:775-788.

17. Kadkhodazadeh M, Tabari ZA, Pourseyediyan T, Najafi K, Amid R. Relationship between Genetic Polymorphisms with Periodontitis and Peri-Implantitis in the Iranian Population: A Literature Review. J Long Term Eff Med Implants 2016;26:183-190.

18. Eguia del Valle A, López-Vicente J, Martínez-Conde R, Aguirre-Zorzano LA. Current understanding of genetic polymorphisms as biomarkers for risk of biological complications in implantology. J Clin Exp Dent 2018;10:e1029-1039.

19. Küchler EC, Tannure PN, Falagan-Lotsch P, Lopes TS, Granjeiro JM, Amorim LMF. Buccal cells DNA extraction to obtain high quality human genomic DNA suitable for polymorphism genotyping by PCR-RFLP and Real-Time PCR. J Appl Oral Sci 2012;20:467-471.

20. Kadkhodazadeh M, Tabari ZA, Ardakani MR, Ebadian AR, Brook A. Analysis of osteoprotegerin (OPG) gene polymorphism in Iranian patients with chronic periodontitis and peri-implantitis. A crosssectional study. Eur J Oral Implantol 2012;5:381-388

21. Kadkhodazadeh M, Ebadian AR, Gholami GA, Khosravi A, Tabari ZA. Analysis of RANKL gene polymorphism (rs9533156 and rs2277438) in Iranian patients with chronic periodontitis and periimplantitis. Arch Oral Biol 2013;58:530-536.

22. Rakic M, Nikolic-Jakoba N, Struillout X, Petkovic-Curcin A, Stamatovic $\mathrm{N}$, Matic $\mathrm{S}$, et al. Receptor activator of nuclear factor kappa B (RANK) as a determinant of peri-implantitis. Vojnosanit Pregl 2013;70,4:346-351

23. Rakic M, Struillou X, Petkovic-Curcin A, Matic S, Canullo L, Sanz M, et al. Estimation of bone loss biomarkers as a diagnostic tool for periimplantitis. J Periodontol 2014;85:1566-1574.

24. Zhou J, Zhao Y. Osteoprotegerin Gene (OPG) Polymorphisms Associated with Peri-implantitis Susceptibility in a Chinese Han Population. Med Sci Monit 2016;22:4271-4276.

25. Ribeiro $R$, Melo $R$, Tortamano Neto $P$, Vajgel $A$, Souza PR, Cimões R. Polymorphisms of II-10 (-1082) and RANKL (-438) Genes and the Failure of Dental Implants. Int J Dent 2017:3901368.

Received August 23, 2019 Accepted September 11, 2019 